\title{
DEVELOPING MATHEMATICS STUDENT ACTIVITY SHEET (SAS) IN TRANSFORMATION FOR SEVENTH GRADE STUDENTS OF SMP/MTS BASED CURRICULUM 2013
}

\author{
Noor Aini ${ }^{1}$, Sumargiyani ${ }^{2}$ \\ SMP Muhammadiyah 1 Kalasan, Glondong, Tirtomartani, Sleman, Indonesia ${ }^{1}$ \\ Universitas Ahmad Dahlan, Jalan Prof. Dr. Soepomo, S.H., Yogyakarta, Indonesia ${ }^{2}$ \\ Email: noor1708050020@webmail.uad.ac.id
}

\begin{abstract}
This research aims to produce teaching materials in form of Student Activity Sheet (SAS) in transformations for students of class VII SMP/MTs based curriculum 2013 and to test the feasibility of SAS in mathematics learning. This research is a development with the steps of Research and Development $(R \& D)$ of ADDIE model (Analysis, Design, Development, Implementation, Evaluation). The research is carried out at SMP N 1 Prambanan Sleman and SMP $N 4$ Kalasan Sleman. The research data is obtained from the questionnaire evaluation media matter by media matter experts, questionnaire evaluation media by media experts, questionnaire evaluation student responses by students. The research data are analyzed by the process of descriptive analysis and the process of analysis questionnaire with Likert scale. The results showed that the SAS of mathematics developed are good quality with an average percentage of ideals $82,416 \%$ and validity criteria by $67,999 \%<\bar{X} \leq 83,998 \%$.
\end{abstract}

Keywords: Student Activity Sheet (SAS), the curriculum 2013, the transformation

\section{INTRODUCTION}

Sari and Syamsi (2015) state that education is one of the basic human needs. The Ministry of Education in Indonesia has sought to address these issues, such as changing the curriculum, improving teacher qualifications, and applying several innovations in mathematics education (Fauzan, 2002). The 2013 curriculum contains the development of multiple intelligence dimensions that can be seen in the first three, on developing competencies consisting of four core competencies (KI), namely spiritual attitudes, social attitudes, knowledge, and skills (Machali, 2014) Therefore, inadequate learning only accommodates the process of exploration, elaboration, and confirmation, but also accommodates the process of observing, asking, reasoning, trying, and forming a 
network ( Tjiptiany, et al, 2016). In mathematics learning mindset developed airsustainability, as proposed Mulyana (2004) in the study Siagian (2013) says mathematics in addition to expanding the horizons of thinking learners can also develop an awareness of the values that are essential contained therein

Nopiyanti (2012) in his research states that the mathematics of learning in school is not only on training skills and memorizing facts, but also on understanding the concept. Not only the results but also how and why the problem is solved in a certain way while still adapting to students' thinking ability. By applying a scientific approach in the process of learning mathematics is expected to materialize students who are productive, creative, innovative, and affective through strengthening attitudes, knowledge and skills (Desstya, 2014). In the study Anisa (2014), a mathematics learning succeed if they produce students who have the ability to problem-solving, communication, reasoning, understanding and the ability of other well and are able to utilize mathematical in life.

In connection with this, it is necessary a tool to support success in the learning process. Wijayanti and Widiyatmoko (2015) stated that one of the teaching materials that can support student learning activities, namely Student Activity Sheet (SAS). Sudrajat (2009) suggests that the SAS are sheets containing the tasks that the student must do (Fannie and Rohati, 2014) SAS contains instructions and steps to complete a task (Dewi, 2013).

But in reality, the SAS compiled by the teacher has not been fully able to pour the students' thought outcomes. Furthermore, the results of interviews at SMP N 1 Prambanan Sleman and SMP N 4 Kalasan Sleman known that the SAS compiled by the teacher only contains a summary of the material with the exercise questions for students. Teachers are still having difficulties finding the SAS model that can be used as a reference for the making of SAS that uses the 2013 curriculum. In addition, students also want SAS that interest their learning, while SAS has been obtained by students in the form of photocopies from SAS made by teachers.

Based on these problems, then as a researcher makes a solution that is developing teaching materials SAS mathematics. Researchers restricted the development of mathematics SAS covers only the transformation of material for students of class VII SMP/MTs, because the material transformation of the material that came into effect 
back in SMP/MTs in the curriculum of 2013 since the enactment of the curriculum SBC.

SAS mathematical transformation material for students of class VII SMP/MTs based curriculum 2013 prepared in accordance with steps SAS good preparation in the Ministry of Education (2008), namely: (1) Analysis of curriculum, (2) Develop a map of the needs of the SAS, (3) Determining SAS titles, (4) Writing SAS covering basic competencies (KD) formulation to be mastered, specifying assessment tools, material preparation, and SAS structures SAS structure created includes title, instructional guidance (student instruction), objectives to be achieved, supporting information, tasks and work steps, and assessment (Nawati and Suparyan, 2015). In the study Dewi, et al (2014), so SAS of mathematics developed able to portray the function and role in effective learning, the SAS has been made then evaluated according to the evaluation covering component the content feasibility aspects, language, presentation and graph.

Using the SAS mathematical transformation material for grade VII students of SMP/MTs based on the developed curriculum of 2013 is expected to improve involvement of students in the learning process and interest in learning mathematics students.

\section{METHOD}

\section{Development style}

This Mathematics Student Activity Sheet Development (SAS) study is in accordance with the steps contained in Research and Development $(R \& D)$ which was developed by Sugiyono by adapting the development model of ADDIE ( Analysis, Design, Development, Implementation, Evaluation ) and Guidance and Development Guides in Depdiknas (Wulandari and Khasanah, 2015).

\section{Development Procedures}

The steps taken in research and development in Sugiyono as revealed by Setyowati, et al (2013) covering 2 aspects, namely the development and feasibility of SAS. SAS development include: (1) Potential and problem, (2) Collecting the data, (3) Product design, (4) Products validation, (5) Design revision. Then the feasibility of SAS includes: (1) Product trial, and (2) Product revision. 


\section{Research and Development Research}

Subjects in this research and development made up of subject matter experts, media experts, and eighth grade students of SMP N 1 Prambanan Sleman and SMP N 4 Kalasan Sleman.

\section{Data Collection Techniques and Instruments}

This development research uses data collection techniques, namely interviews and questionnaires. The research data was obtained by using data collection instrument, among others, the feasibility of the material expert, the media expert feasibility test instrument, and the student's test response instrument.

The data that has been collected, in can be calculated the average by the formula:

$$
\bar{X}=\frac{\sum_{i=0}^{n} X_{i}}{N}
$$

Information:

$$
\begin{array}{ll}
\bar{X} & : \text { Average score } \\
\sum_{i=0}^{n} X_{i} & : \text { Total score } \\
\mathrm{N} & : \text { Number of appraisers }
\end{array}
$$

Furthermore, from the data obtained from material experts, media experts and students of class VIII is changed to a qualitative value based on the assessment criteria ideal. The terms of the ideal scoring criteria are shown in Table 1.

\section{Table 1. Ideal Rating Criteria}

\begin{tabular}{|l|c|l|}
\hline No. & Score Range (i) Quantitative & \multicolumn{1}{|c|}{ Qualitative Category } \\
\hline 1. & $\bar{X}>\overline{M_{i}}+1,8 S B_{i}$ & Very Good \\
\hline 2. & $\overline{M_{i}}+0,6 S B_{i}<\bar{X} \leq \overline{M_{i}}+1,8 S B_{i}$ & Good \\
\hline 3. & $\overline{M_{i}}-0,6 S B_{i}<\bar{X} \leq \overline{M_{i}}+0,6 S B_{i}$ & Enough \\
\hline 4. & $\overline{M_{i}}-1,8 S B_{i}<\bar{X} \leq \overline{M_{i}}-0,6 S B_{i}$ & Not Good \\
\hline 5. & $\bar{X} \leq \overline{M_{i}}+1,8 S B_{i}$ & Very Less \\
\hline
\end{tabular}

(Ariani and Widjajanti, 2013)

\section{RESULT AND DISCUSSION}

\section{Trial Data}

The trial data in this development study were obtained by the following steps. 
1. Determination of Potentials and Problems

At this stage, reference studies were conducted from various sources, discussions with supervisors about potentials and problems in SAS development, interview with teacher of math class VII SMP N 1 Prambanan Sleman and SMP N 4 Kalasan Sleman on the use of teaching materials in learning curriculum 2013, interviews with students about teaching materials used and created by teachers, as well as librarians at SMP N 1 Prambanan Sleman and SMP N 4 Kalasan Sleman on the availability of materials teaching used in learning.

2. Data collection

At this stage, reference studies from various sources, both from the internet and print media related to information used in developing SAS.

3. Preparation of SAS Products

a. Curriculum Analysis

Analysis done by looking at the subject matter and learning experience of the transformation material, then the competence that must be owned by the students.

b. Preparing SAS Need Map

The SAS need map is a SAS diagram and to determine the amount of SAS to be written.

c. Specifying Title of SAS

In this stage, SAS titles have been developed, including translation, reflection, rotation, and dilatation.

d. Writing SAS

The developed SAS has the following characteristics.

1) The SAS contents are tailored to the KI and KD developed based on the 2013 curriculum.

2) Using simple language.

3) SAS uses images and illustrations that match the material.

\section{Product Validation}

The validation stage of this development research is carried out by media experts and material experts using the instrument in the form of a pre- selected questionnaire. Revisions are made based on inputs and suggestions from experts. 


\section{Product Trial}

SAS that has been validated by material experts and media experts then conducted trial I to 20 students consisting of 10 students of grade VIII SMP N 1 Prambanan Sleman and 10 students of class VIII SMP N 4 Kalasan Sleman selected at random.

After conducting trial I, then the next step is to conduct trial II. This trial consists of 63 students, 31 students from SMP N 1 Prambanan Sleman and 32 students of SMP N 4 Kalasan Sleman.

\section{Data analysis}

1. Material Questionnaire Analysis

The SAS mathematical assessment was conducted by three material experts. The result of questionnaire assessment by expert material obtained an average score of 110,333 . This indicates that $\bar{X}>105,006$, so that SAS of mathematics developed in terms of material fall into the category very good.

2. Media Questionnaire Analysis

The SAS mathematical assessment was performed by one media expert. The result of questionnaire assessment by media experts obtained an average score of 88 . The results show that $74,802<\bar{X} \leq 92,406$. So SAS of mathematics developed in terms of media included in good categories.

3. Student Response Questionnaire Analysis

The result of student responses on the first trial in the SMP N 1 Prambanan Sleman obtained an average score of 68,900 questionnaires calculation results, whereas in the second trial gained an average score calculation results questionnaire 69,53. Then for the results of student responses in the trial I in SMP N 4 Kalasan Sleman obtained average score of calculation results 72,900 questionnaire, while in trial II obtained the average score of the calculation results of 73,000 questionnaires. From the experiments conducted can be obtained the calculation of the average overall questionnaire responses of 71,083 students. Obtaining any calculation results of the student questionnaire responses were the valid criteria $61,200<\bar{X} \leq$ 75,600 , so the SAS of mathematics developed in good categories. 
4. Joint Assessment Analysis of Student Assessment and Response

The combined results of questionnaires by mathematics material experts, media experts, and student responses are shown in Table 2.

Table 2. Overall SAS Quality Calculation Results

\begin{tabular}{|l|l|c|c|c|}
\hline No. & $\begin{array}{c}\text { Aspect of } \\
\text { Assessment }\end{array}$ & Average Score & $\begin{array}{c}\text { Maximum Score } \\
\text { Idea }\end{array}$ & $\begin{array}{c}\text { Percentage of } \\
\text { Idea }\end{array}$ \\
\hline 1. & Material experts & 110,333 & 125 & $88,266 \%$ \\
\hline 2. & Media experts & 88 & 110 & $80 \%$ \\
\hline 3. & Student response & 71,083 & 90 & $78,981 \%$ \\
\hline \multicolumn{2}{|l|}{ Total score } & 269,416 & 325 & - \\
\hline \multicolumn{2}{|l|}{ Average Percentage of Idea } & - & $82,416 \%$ \\
\hline
\end{tabular}

From the calculation result of a composite questionnaire of material experts, media experts, and student response questionnaires with a combined average score of 269,416 from a maximum score of 325 obtained per ideality percentage of $82,416 \%$. The results show that $67,999 \%<\bar{X} \leq 83,998 \%$. Thus the quality of SAS mathematical transformation material for grade VII students of SMP/MTs based on the developed curriculum 2013 included in both good and feasible criteria used in the learning process.

\section{Product Revision}

Media mathematics that has been assessed by subject matter experts, media experts, and students then revised according to feedback improvements that have been given. Here is some feedback from the experts.

1. Adding a matter of subject and object (plane) are cut off axis reflection, then equipped with the points are invariant (unchanged). 
Aini \& Sumargiyani, Developing Mathematics Student Activity Sheet (SAS) in Transformation for Seventh Grade Students of SMP/MTs Based Curriculum 2013

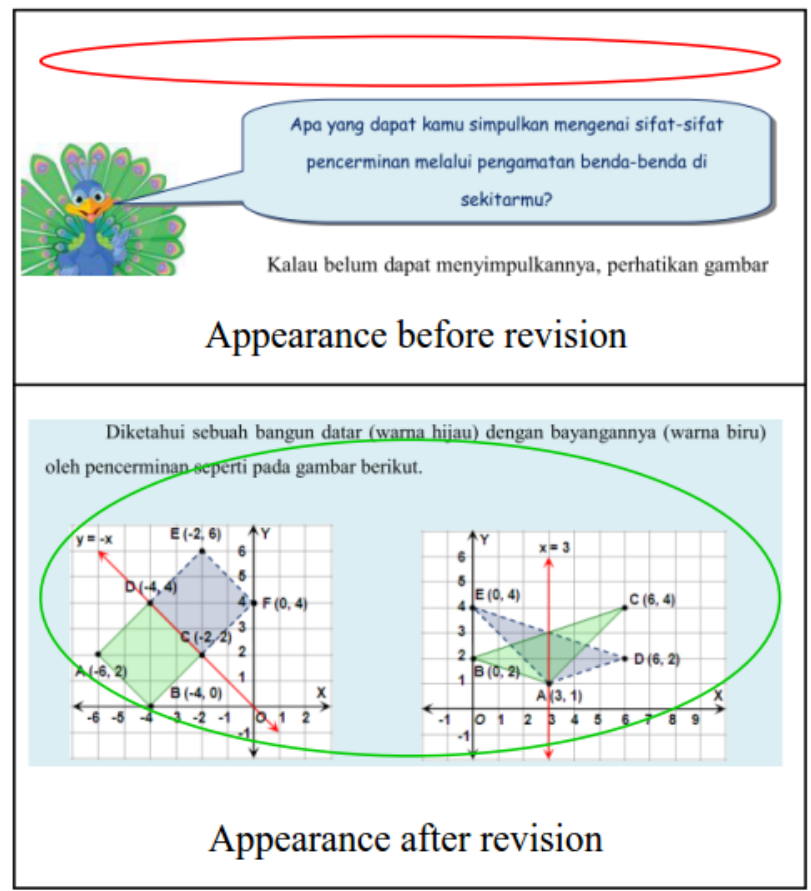

Figure 1. Revision Results of Reflection Question

2. Changing the font size on the image on the page map SAS notch math becomes larger.

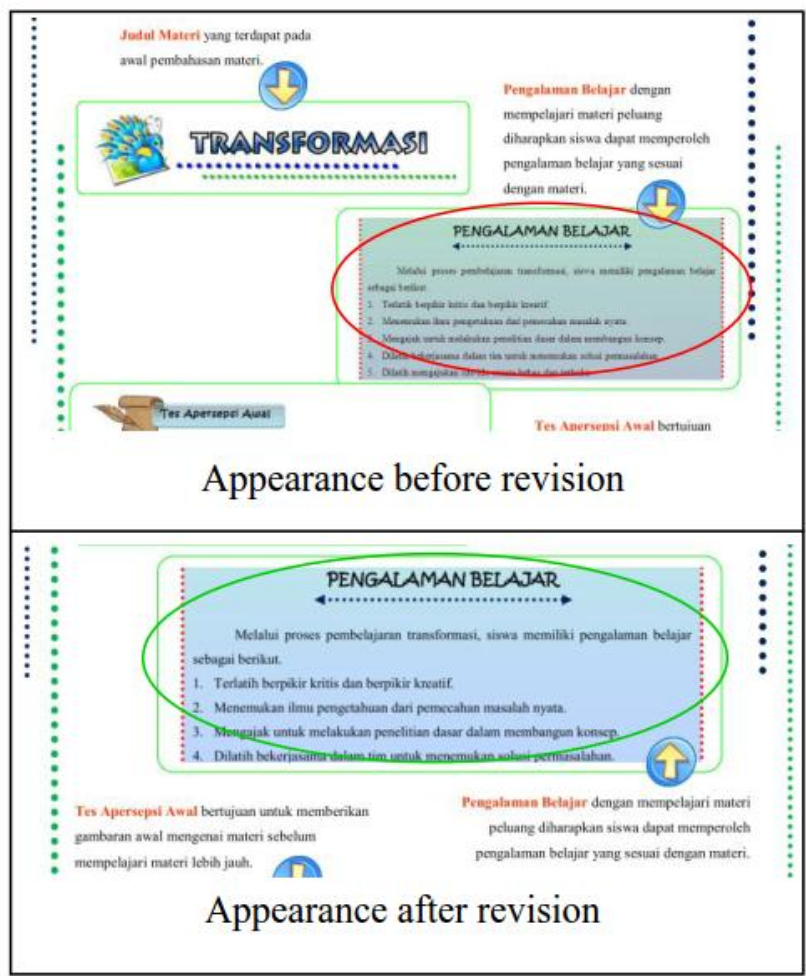

Figure 2. Revision Result of SAS Position Page 
3. Adding dilatation question with dilation center located on wake to dilate.

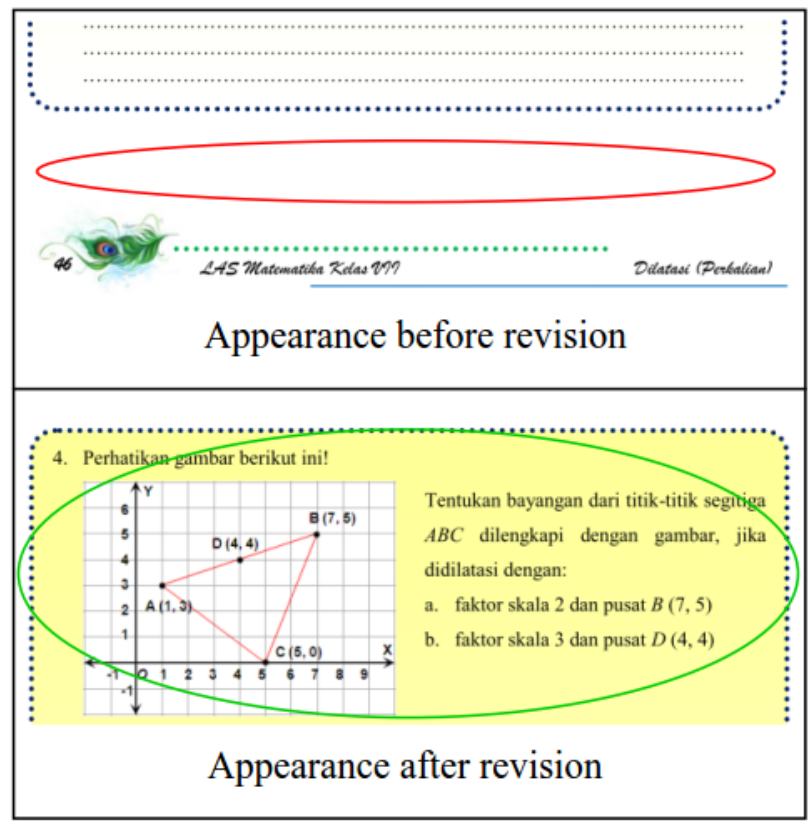

Figure 3. Revision Results of Dilatation Question

\section{Final Product Review}

The research and development has successfully compiled SAS mathematical transformation material for grade VII students SMP/MTs based on the curriculum 2013.

\section{CONCLUSSION}

After the Mathematics Activity Sheet (SAS) developed was revised according to inputs and suggestions from media experts and material experts, then conducted trial I and trial II to find out the student response to SAS developed mathematics. Based on the assessment, it can be concluded that in general SAS of mathematics developed included in either category and suitable for teachers to teach and students to study independently in school or outside school.

\section{REFERENCE}

Anisa, W.N. (2014). Peningkatan Kemampuan Pemecahan Masalah Dan Komunikasi Matematik Melalui Pembelajaran Pendidikan Matematika Realistik untuk Siswa SMP Negeri di Kabupaten Garut. Jurnal Pendidikan dan Keguruan, 1(1), 8-15.

Ariani, A., \& Widjajanti, D.B. (2013). Pengembangan Perangkat Pembelajaran Geometri SMP dengan Pendekatan Open-Ended Berorientasi Kemampuan 
Berpikir Kritis. PYTHAGORAS: Jurnal Pendidikan Matematika, 8(1), 21-32.

Desstya, A. (2014). Kedudukan dan Aplikasi Pendidikan Sains Di Sekolah Dasar. Publikasi Ilmiah UMS, 1(2), 193-200.

Dewi, A.P., Sarwanto, \& Prayitno, B.A. (2014). Pengembangan Modul IPA Terpadu untuk SMP/MTs Berbasis Eksperimen pada Tema Fotosintesis untuk Memberdayakan Keterampilan Proses Sains. Jurnal Inkuiri, 3(3), 30-40.

Dewi, D.R. (2013). Pengembangan Lembar Kerja Siswa Untuk Pembelajaran Permutasi Dan Kombinasi Dengan Pendekatan Kontekstual Untuk Siswa SMA Kelas XI. Jurnal Online Universitas Negeri Malang

Fannie, R.D., \& Rohati. (2014). Pengembangan Lembar Kerja Siswa (LKS) Berbasis Poe (Predict, Observe, Explain) Pada Materi Program Linear Kelas XII SMA. Jurnal Sainmatika, 8(1), 96-109

Fauzan, A. (2002). Applying Realistic Mathematics Education (RME) in Teaching Geometry In Indonesian Primary Schools. Research University of Twente December 2002

Haryati, S. (2012). Research and Development (R\&D) Sebagai Salah Satu Model Penelitian dalam Bidang Pendidikan. Open Journal System Indonesia, 37(1), 1126.

Machali, I. (2014). Dimensi Kecerdasan Majemuk Dalam Kurikulum 2013. Insania: Jurnal Pemikiran Alternatif Kependidikan, 19(1), 21-45.

Nawati, A., \& Suparyan. (2015). Pengembangan Lembar Aktivitas Siswa(LAS) Pokok Bahasan relasi dan Fungsi Berbasis Contextual Teaching and Learning (CTL) untuk Siswa SMP/MTs Kelas VIII. AdMathEduSt, 2(1), 19-26.

Nopiyanti, N.L.P.A., (2012). Pengembangan Perangkat Pembelajaran Geometri Berbantuan Geogebra dalam Upaya Meningkatkan Keterlibatan dan Prestasi Belajar Matematika Siswa Kelas VII. Jurnal Pendidikan Matematika Indonesia, $1(2), 1-12$.

Sari, I.P., \& Syamsi, K. (2015). Pengembangan Buku Pelajaran Tematik-Integratif Berbasis Nilai Karakter Disiplin Dan Tanggung Jawab di Sekolah Dasar. Jurnal Prima Edukasia, 3(1), 73-83.

Setyowati, R., Parmin, P., \& Widiyatmoko, A. (2013). Pengembangan Modul IPA Berkarakter Peduli Lingkungan Tema Polusi Sebagai Bahan Ajar Siswa SMK N 11 Semarang. Unnes Science Education Journal, 2(2), 245-253.

Siagian, R. E. F. (2013). Pengaruh Minat dan Kebiasaan Belajar Siswa Terhadap Prestasi Belajar Matematika. Jurnal Formatif, 2(2), 122-131. 
Suti, M. (2011). Strategi Peningkatan Mutu di Era Otonomi Pendidikan. Jurnal Medtek, $3(2)$.

Syahrir. (2016). Pengembangan Perangkat Pembelajaran Matematika SMP untuk Meningkatkan Kemampuan Berfikir Kreatif. Jurnal Ilmiah Mandala Education (JIME), 2(1), 436-441.

Taufikurrahman. (2015). Pengembangan Lembar Aktivitas Siswa (LAS) untuk SMP Kelas VIII Materi Operasi Bnetuk Aljabar dengan Prinsip Belajar Bermakna. AdMathEduSt, 2(1), 201-210.

Tjiptiany, E. N., As'ari, A. R., \& Muksar, M. (2016). Pengembangan Modul Pembelajaran Matematika dengan Pendekatan Inkuiri untuk Membantu Siswa SMA Kelas X dalam Memahami Materi Peluang. Jurnal Pendidikan: Teori, Penelitian, dan Pengembangan, 1(10), 1938-1942.

Wijayanti, F., \& Widiyatmoko, A. (2015). Pengembangan LKS IPA Berbasis Multiple Intelligences pada Tema Energi Dan Kesehatan untuk Meningkatkan Kemampuan Berpikir Kreatif Siswa. Unnes Science Education Journal, 4(1), 772-779.

Wulandari, Y. I, \& Khasanah, U. (2015). Pengembangan Lembar Aktivitas Siswa (LAS) Materi Statistika untuk Siswa Kelas VII SMP/MTs Berdasarkan Kurikulum 2013. AdMathEduSt, 2(1), 229-238. 